\title{
Classification of Shared Values for Educational Research
}

\author{
I. Yogamalar \\ Research Scholar, VIT Business School, VIT University, Chennai, India \\ E-mail: yogamalar@gmail.com
}

Anand A. Samuel

Vice -Chancellor, VIT University, Vellore, India

E-mail: vc@vit.ac.in

Received: Jan. 31, 2018 Accepted: Feb. 26, 2018 Online published: Mar. 13, 2018

doi:10.5296/ijhrs.v8i2.12818ＵRL: https://doi.org/10.5296/ijhrs.v8i2.12818

\begin{abstract}
The main aim of this article is to derive the list of shared values from academic perspective. The value statements were collected through qualitative procedure. The adapted version of McDonald and Gandz (1991) and the qualitative value statements provided by the respondents were combined together to prepare the list of shared values. Descriptive methods such as median, percentage agreement, item ambiguity, content validity index, content validity ratio, and content validity coefficient were employed to conclude the expert's rating in content validity analysis. The exploratory factor analysis (EFA) is a popular mathematical procedure to determine the underlying structure of the variables. The maximum likelihood extraction method and promax rotation method were chosen to extract the factors and eventually six factors were finalized. The six factors were named in order to represent the underlying variables. The confirmatory factor analysis (CFA) was also carried out to determine the goodness-of-fit to the data and ultimately the reliability test was done to ensure the consistency of the factors and the scale. The Cronbach's alpha value confirmed that the scale is consistent for further analysis.
\end{abstract}

Keywords: shared values, academic institution, EFA, CFA, content analysis, maximum likelihood, promax rotation

\section{Introduction}

Higher educational institution is a pool where the employees for various professions are 
being prepared. It has a critical role in preparing the workforce (Lawrence \& Lawrence, 2009). In this contemporary world, the educational institutions play a significant phase in molding the future employees. It is apparently seen that it is the place where various generation groups interact so often and tend to observe each other's value systems. The greatest responsibility of a management is to gather various generational cohorts under one roof and direct them in one way to attain the core values of the institution. It is evident from the various generational researches that each generation group has a unique set of values and characteristics. Strauss and Howe (1997) defined generational categories, as baby boomers (born between 1943 and 1960); Gen X (born between 1961 and 1981) and Gen Y or Millennials (born between 1982 and 2004).

Baby boomers give more importance to hard work and achievement (Collins, 1998); health (Gibson et al., 2009). Gen X tends to establish strong communal relationships with colleagues (Raineri et al., 2012) and more committed to their jobs (Lyons, 2004); whereas Gen Y focuses more on accomplishment (Gibson et al., 2009) and work liberty (Cennamo \& Gardner, 2008). So, it is imperative to explore the shared values of various generational cohorts in higher educational institutions. Hence, the current article has attempted to present the list of shared values from academic perspective by adapting McDonald and Gandz's (1991) taxonomy of values.

\section{The Importance of Shared Values in Academic Institutions}

Over the past two decades, the concept of shared values has been explored widely (Kristof, 1996; Westerman and Vanka, 2005). The shared values or person- organisational values fit (P-O fit) has a positive influence on work adjustment, and career success (Adkins et al., 1994); organizational commitment (Finegan, 2000) and job satisfaction (Ostroff et al., 2005).

The shared values become a salient HR issue in the workplace and it is one of the approaches to get unfathomable levels of individual-organizational integration and high employee commitment (Macdonald \& Gandz, 1991). In the academic institutions, the management, the employees, and students (different generational groups) need to understand the paramount importance of shared values in the workplace. Each institution is functioning based on its core values framed by the management. The present article has postulated the list of value statements from academic perspective in addition to the core values for the success of the institution. The measure of individual-organizational congruence will enable the researchers to explore positive behavior of employees, work attitudes, individual and organizational outcomes.

\section{The Concept of Values}

Rokeach has defined values as "enduring beliefs that a specific mode of conduct is personally or socially preferable to an opposite or converse mode of conduct or end-state of existence" (Rokeach 1973, p. 5).

Values have significant impact on attitudes and behaviors (Brown, 2002) and it is the fundamental concept for the purpose and goal of an organization (Posner, 2010a). Posner states: "They are the heart of the culture of an organization" (2010b, p.536). Each individual 
is unique and a value which is important to one person may not be the same to the other (Yogamalar \& Samuel, 2016). So far, many researchers like Allport et al. (1960); England, (1967); Rokeach, (1973); Schwartz, (1992); Schwartz and Bardi, (2001) had presented the instruments to measure the values at individual values but could not be employed to measure organizational values as well as the individual-organizational congruence.

McDonald and Gandz (1991) adapted Rokeach's (1973) list of values and proposed 'the taxonomy of 24 value dimension' to evaluate the values at the individual and organizational level. In the recent years, many researchers (Abbott et al. 2005; Finegan, 2000; Lawrence, 2006; Lawrence and Lawrence, 2009; McDonald and Gandz, 1992) have manipulated the taxonomy of 24 value dimensions to explore its impact on commitment. But, the above specified list of values has focused only on the business aspect. The shared values measurement is not available for higher educational institutions. We cannot operate the former list to academic field as the preferable values of business people differ from academic people as both of them are non-identical in their targets. Hence, this article has focused on deriving the list of shared values statements from academic perspective and explored the factor structure by administering exploratory factor analysis (EFA).

\section{Method}

McDonald and Gandz's (1991) taxonomy of values had been adapted for this study. To derive the list of shared values from academic perspective, semi-structured interview was conducted with 103 respondents and it comprised of Senior Professors, Professors, Associate Professors, Assistant Professors (Sr.), Assistant Professors (Jr.), Administrative staff, PhD scholars, students from engineering, management, and arts background. Their qualitative responses were recorded in written format. The interview was conducted for 15 to 20 minutes. In addition to their responses, the value statements had been collected from the prospectus of 30 AICTE (All India Council for Technical Education) recognized higher educational institutions in India. For qualitative data collection, Creswell (2003) described 4 types of procedure: observations, interviews, documents and audio visual methods.

In this present study, two methods (interview and document) have been followed to collect the value statements from the respondents. Table 1 displays the members included in the interview.

Table 1. Respondents included for deriving qualitative responses regarding the shared values

\begin{tabular}{l|l|l|c}
\hline $\begin{array}{c}\text { Methods } \\
\text { of } \\
\text { collecting } \\
\text { responses }\end{array}$ & \multicolumn{1}{|c|}{ Groups } & \multicolumn{1}{|c}{ Category } & \multicolumn{1}{c}{$\begin{array}{c}\text { No. of } \\
\text { Respondents }\end{array}$} \\
\hline & & Senior Professors & 6 \\
Semi - & Group 1 & Professors & 5 \\
structured & Teaching Staff & Associate Professors & 7 \\
Interview & Assistant Professors (Sr.) & 10 \\
& Group 2 & Assistant Professors (Jr.) & 10 \\
\cline { 2 - 4 } & Non- teaching Staff & Administrative Staff & 15 \\
\hline
\end{tabular}




\begin{tabular}{l|l|l|c}
\hline & $\begin{array}{l}\text { Group 3 } \\
\text { Students }\end{array}$ & $\begin{array}{l}\text { Ph.D Scholars } \\
\text { Students from } \\
\text { engineering, management } \\
\text { \& arts background }\end{array}$ & 35 \\
\hline Document & $\begin{array}{l}\text { Group 4 } \\
\text { Prospectus }\end{array}$ & $\begin{array}{l}\text { AICTE recognized } \\
\text { educational institutions }\end{array}$ & 30 \\
\hline
\end{tabular}

Table 2. McDonald and Gandz (1991) list of values and proposed list of values

\begin{tabular}{|c|c|c|c|c|c|c|}
\hline \multirow{3}{*}{ S.No } & \multirow{3}{*}{$\begin{array}{c}\text { List of values } \\
\text { proposed by } \\
\text { McDonald and Gandz } \\
\text { (1991) }\end{array}$} & \multicolumn{5}{|c|}{ Proposed list of values } \\
\hline & & \multirow[t]{2}{*}{ Value statements } & \multicolumn{2}{|c|}{$\begin{array}{l}\text { Core values stated } \\
\text { by AICTE } \\
\text { recognized } \\
\text { educational } \\
\text { institutions }\end{array}$} & \multicolumn{2}{|c|}{$\begin{array}{l}\text { Values } \\
\text { statements given } \\
\text { by the } \\
\text { respondents }\end{array}$} \\
\hline & & & $\mathrm{n}_{1}=30$ & $\%$ & $\mathrm{n}_{2}=103$ & $\%$ \\
\hline 1. & Moral Integrity & $\begin{array}{l}\text { Integrity / Academic } \\
\text { Integrity }\end{array}$ & 6 & 20 & 52 & 50.5 \\
\hline 2. & Autonomy & Academic Freedom & 5 & 16.7 & 77 & 74.8 \\
\hline 3. & Creativity & Creativity & 6 & 20 & 63 & 61.17 \\
\hline 4. & Development & $\begin{array}{l}\text { Development of } \\
\text { students }\end{array}$ & 5 & 16.7 & 60 & 58.25 \\
\hline 5. & Cooperation & $\begin{array}{l}\text { Personality } \\
\text { developments }\end{array}$ & 6 & 20 & 98 & 95.15 \\
\hline 6. & Initiative & Spirit of participation & 10 & 33.3 & 62 & 60.2 \\
\hline 7. & Aggressiveness & Quality education & 9 & 30 & 82 & 79.61 \\
\hline 8. & Fairness & Value based education & 10 & 33.3 & 16 & 15.53 \\
\hline 9. & Diligence & $\begin{array}{l}\text { Inculcating moral } \\
\text { values }\end{array}$ & 5 & 16.7 & 89 & 86.4 \\
\hline 10. & Experimentation & Benefit of society & 12 & 40 & 22 & 21.36 \\
\hline 11. & Adaptability & Changing the society & 9 & 30 & 39 & 37.9 \\
\hline 12. & Courtesy & Competent & 5 & 16.7 & 60 & 58.25 \\
\hline 13. & Cautiousness & Techsavvy & 10 & 33.3 & 52 & 50.49 \\
\hline 14. & Social equality & $\begin{array}{l}\text { Creating effective } \\
\text { professional leaders }\end{array}$ & 2 & 6.7 & 12 & 11.65 \\
\hline 15. & Economy & $\begin{array}{l}\text { Creating effective } \\
\text { entrepreneurs }\end{array}$ & 4 & 13.3 & 19 & 18.45 \\
\hline 16. & Consideration & Leadership skills & 15 & 50 & 76 & 73.79 \\
\hline 17. & Formality & Commitment & 12 & 40 & 59 & 57.28 \\
\hline 18. & Humor & Research & 20 & 66.7 & 81 & 78.64 \\
\hline 19. & Forgiveness & Meritocracy & 2 & 20 & 33 & 32.03 \\
\hline 20. & Broad-mindedness & $\begin{array}{l}\text { Excellence in } \\
\text { scientific \& technical / } \\
\text { Intellectual Excellence }\end{array}$ & 9 & 30 & 24 & 23.3 \\
\hline 21. & Logic & $\begin{array}{l}\text { Innovation / } \\
\text { Innovative teaching }\end{array}$ & 13 & 43.3 & 78 & 75.72 \\
\hline $\begin{array}{l}22 . \\
23 . \\
24 .\end{array}$ & $\begin{array}{l}\text { Openness } \\
\text { Obedience } \\
\text { Orderliness }\end{array}$ & Advance knowledge & 12 & 40 & 101 & 98.05 \\
\hline
\end{tabular}

After evaluating the qualitative responses of the respondents and core values stated on the prospectus, 22 items were derived. The four items proposed by McDonald and Gandz (1991) 
such as moral integrity, autonomy, creativity and development were coincided with the proposed statements like academic integrity, academic freedom, creativity and development of students / personality development respectively. Hence, the former statements (represented from business perspective) were replaced by the latter items. For example, 'autonomy' refers to 'freedom' not 'constrained by many rules' (Chatman, 1989). Here, 'academic freedom' refers to "the freedom of teachers and students to teach, study, and pursue knowledge and research without unreasonable interference or restriction from law, institutional regulations, or public pressure" (The Editors of Encyclopaedia Britannica, 2010). The remaining items from both the lists were included for the further analysis.

\section{Content Validity}

Any measurement that we take for research should measure what we intend to measure. To ensure it, sundry types of validity tests are prevailing. Content validity is one among them. It is the responsibility of the researcher to evolve high support for the validity of their measures (Bollen, 1989). Content validity is based on the judgment of experts regarding the content relevancy of the test domains and representation of items to their domains (Rogers, 2010). The following topics have revealed the procedures to be followed in the selection of experts and rating their judgments.

\subsection{Expert Judgment}

This phase is to assess to what extent the items that were created represent the target and aspect of construct (Beck and Gable, 2001). In this study, the items were evaluated based on the relevance and representativeness. When there is high rating of relevance and representativeness, the better the content validity rating is.

\subsection{Entreat Expert Participation}

Initially, an invitation was sent to the experts. The experts who expressed their desire to participate were sent an attachment containing,

- Covering letter, and

- Content rating review form

Participants were given 3 weeks to complete the review form and mail it back to the researcher. The covering letter explained the main objective, purpose of the study, target population and the aim of collecting the content rating review form. The content rating review form encompassed the instructions and procedures to be followed to accomplish the rating pattern. It consisted of 5 columns. First column placed the items to be evaluated. Second column showed the rating scale 0 to 4 where the experts were expected to rate the item. Third column represented "Is the item well written?" - Yes / No and fourth column denoted "Is the item essential to the domain?" - Yes / No. The experts were supposed to mark yes or no on both the columns. The fifth column had given space for the experts to place their suggestions, ideas, opinions, and items to be revised. 


\subsection{Selection of the Experts}

In selecting the panel of experts, the criteria outlined by Yun and Ulrich (2002) were used as a point of reference. Experts were selected on the premise of their job title, experience, knowledge on research and paper publications. A total of 15 HR \& OB Professors from diverse universities and colleges in India were invited to participate as content evaluation experts. Out of 15,8 professors accepted the invitation and participated.

Table 3. Selection of Experts based on the experience

\begin{tabular}{c|c|c|c}
\hline Experts & Category & Area of expertise & Years of experience \\
\hline 1 & Academic & HR \& OB & 15 \\
2 & Academic & HR \& OB & 10 \\
3 & Academic & HR \& OB & 11 \\
4 & Academic & HR \& OB & 17 \\
5 & Academic & HR \& OB & 20 \\
6 & Academic & HR \& OB & 12 \\
7 & Academic & HR \& OB & 10 \\
8 & Academic & HR \& OB & 15 \\
\hline
\end{tabular}

\subsection{Perusal of Expert Ratings}

Three major approaches such as descriptive, quantitative, and qualitative were classified to analyze experts' ratings by Hellsten (2008). The present study has focused only two approaches like descriptive and quantitative approaches but qualitative approach was not able to perform due to time constraint.

\subsubsection{Descriptive Approach}

- Median: A higher median value indicated a more relevant item. The present study has used a rating scale of 0 to 4 , and an item with a median value of 2.75 and above is accounted for acceptance (Hellsten, 2008).

- Item Ambiguity: The item ambiguity score for each item has been calculated. Items with lower ambiguity scores are desired as they indicate consensus among judges. The rating scale of 0 to 4 which is used in this research, a range of 3 or more between scores (or $\mathrm{R}_{\mathrm{k}}$ of 4 or higher) is considered ambiguous. Hence, low ambiguity values such as 1, 2 or 3 are acceptable for this study. When the value of IA is 4 or more, then the ambiguity is more. We need to think of removing such an item, but we should not take decision just by noticing this value alone, instead the other methods need to be considered for deleting any item.

- Percentage Agreement: $80 \%$ of agreement of judges is considered as acceptable.

\subsubsection{Quantitative Approach}

- Content Validity Index (CVI): CVI for each individual item is the percentage of judges who have rated the item as 3 or 4 (Lynn, 1986). Polit, Beck and Owen (2007) observed that the CVI value of 1.00 is acceptable for panels of three or four experts, whereas 0.80 was considered acceptable for a panel of 5 members. The table 4 denotes the rating of experts and content validity index value. 
Table 4. Content validity Index value and Evaluation

\begin{tabular}{c|c|c|c}
\hline No. of Experts & $\begin{array}{c}\text { No. of experts } \\
\text { rating } 3 \text { or } 4\end{array}$ & CVI & Evaluation \\
\hline 8 & 8 & 1.00 & Excellent \\
8 & 7 & 0.88 & Excellent \\
8 & 6 & 0.75 & Good \\
\hline
\end{tabular}

- Content Validity Ratio: The CVR range should be -1 to +1 . The number was equal to zero when half of the judges rated the item as essential (Lawshe, 1975). The minimum CVR for each item to be considered as acceptable was 0.75 for a one-tailed test at the $95 \%$ confidence level, if a minimum of 8 judges were used for the study (Lawshe, 1975). In this study, 8 judges have participated; the CVR value 0.75 was accepted for the present study.

- Content Validity Coefficient $\left(\mathbf{V I}_{\mathbf{k}}\right)$ : An item is highly accepted if the coefficient was closer to 1 . The coefficient value is compared with a table of right-tail probabilities (p) to determine the significant value (Aiken, 1985, p.133). For 8 experts, the significant value was $\mathrm{v}=0.75$ and $\mathrm{p}=0.40$.

Table 5. Formula for the Descriptive and Quantitative methods

\begin{tabular}{|c|c|c|}
\hline $\begin{array}{l}\text { Descriptive } \\
\text { Approach }\end{array}$ & Formula & Description \\
\hline Median & $\begin{array}{l}\text { If } \mathrm{n} \text { is odd, then median }(\mathrm{M}) \\
\quad=((\mathrm{n}+1) / 2)) \\
\text { If } \mathrm{n} \text { is even, then median }(\mathrm{M}) \\
\quad=[(\mathrm{n} / 2)+((\mathrm{n} / 2)+1)] / 2\end{array}$ & $\mathrm{n}=$ no. of Experts \\
\hline $\begin{array}{l}\text { Item ambiguity } \\
\text { (IA) }\end{array}$ & $\mathrm{R}_{\mathrm{k}}=\left(\mathrm{X}_{\mathrm{kjh}}-\mathrm{X}_{\mathrm{kjl}}\right)+1$ & $\begin{array}{c}\mathrm{X}_{\mathrm{kjh}} \text { is the items' highest rating } \\
\mathrm{X}_{\mathrm{kjl}} \text { is the lowest rating }\end{array}$ \\
\hline $\begin{array}{c}\text { Percentage } \\
\text { Agreement (PA) }\end{array}$ & $\begin{array}{c}=(\text { No. of experts rated "YES" I } \\
\text { Tot. no. of experts) } * 100\end{array}$ & \\
\hline $\begin{array}{l}\text { Quantitative } \\
\text { Approach }\end{array}$ & Formula & Description \\
\hline $\begin{array}{l}\text { Content Validity } \\
\text { Index } \\
\text { (CVI) }\end{array}$ & $\begin{array}{c}=\text { (No. of experts who rated } 3 \text { or } \\
4 / \text { Tot. no. of experts })\end{array}$ & CVI is expressed in percentage \\
\hline $\begin{array}{l}\text { Content Validity } \\
\text { Ratio } \\
\text { (CVR) }\end{array}$ & $\mathrm{CVR}_{\mathrm{i}}=\left(\mathrm{n}_{\mathrm{e}}-\mathrm{N} / 2\right) /(\mathrm{N} / 2)$ & $\begin{array}{l}\text { - } \mathrm{CVR}_{\mathrm{i}} \text { is the value of CVR for } \\
\text { the } \mathrm{i}^{\text {th }} \text { item } \\
\text { - } \mathrm{n}_{\mathrm{e}} \text { is the no. of experts indicated } \\
\text { that the item is essential } \\
\text { - } \mathrm{N} \text { is the no. of experts on the } \\
\text { panel } \\
\text { - } \text { CVR ranges from }-1 \text { to }+1\end{array}$ \\
\hline $\begin{array}{l}\text { Content Validity } \\
\text { Coefficient } \\
\left(\mathrm{VI}_{\mathrm{k}}\right)\end{array}$ & $\mathrm{VI}_{\mathrm{k}}=\mathrm{S} /[\mathrm{j}(\mathrm{c}-1)]$ & $\begin{array}{l}\text { - } \quad \mathrm{S} \text { is the sum of } s_{j}\left(s_{j}=r_{j}-l_{o}\right) \\
\text { - } r_{j} \text { is the } j \text { 's ratings } \\
\text { - } l_{0} \text { is the lowest rating of } j^{\text {th }} \text { item } \\
\text { - } j \text { is the tot. no of experts } \\
\text { - c is the no. of rating categories } \\
\text { - } s_{j} \& r_{j}(j \text { represents } 1,2,3 \ldots n \\
\text { experts })\end{array}$ \\
\hline
\end{tabular}


Table 5a. Acceptable Range for Content Validity

\begin{tabular}{c|c|c|c|c|c}
\hline Median & $\begin{array}{c}\text { Item } \\
\text { Ambiguity }\end{array}$ & $\begin{array}{c}\text { Percentage } \\
\text { Agreement }\end{array}$ & $\begin{array}{c}\text { Content } \\
\text { validity } \\
\text { index }\end{array}$ & $\begin{array}{c}\text { Content } \\
\text { validity } \\
\text { ratio }\end{array}$ & $\begin{array}{c}\text { Content } \\
\text { validity } \\
\text { coefficient }\end{array}$ \\
\hline $\begin{array}{c}2.75 \text { or } \\
\text { above }\end{array}$ & $1,2 \& 3$ & $80 \%$ & 0.75 & 0.75 & 0.75 \\
\hline
\end{tabular}

Descriptive and quantitative approaches are applied to determine the content validity of the items. Out of six, any item satisfies less than four methods, it should be deleted and if any item satisfies more than 3 methods that should be retained. Table 5 has displayed the formulas for calculating three methods of descriptive approach and three methods of quantitative approach. Table 5a discloses the acceptable values for six methods in the present study. Table 6 shows the list of value statements, judge's rating for each method, and decision to retain or remove the items. The items such as cooperation, aggressiveness, social equality and consideration are replaced by the items such as teamwork, assertiveness, equality in opportunities and recognition respectively based on the suggestions of judges. The seven items such as assertiveness, courtesy, economy, formality, broad-mindedness, emerging as an effective professional leaders/skills/entrepreneurs, and commitment were removed as they satisfied less than 4 methods. Eventually, the final list comprised of 30 items and this final list was taken for data collection for performing EFA.

Table 6. Content validity report based on the judges' rating.

\begin{tabular}{c|l|c|c|c|c|c|c|c}
\hline S.No & \multicolumn{1}{|c|}{ List of Values } & Median & IA & PA & CVI & CVR & VI $\mathrm{k}_{\mathrm{k}}$ & $\begin{array}{c}\text { Decision } \\
\text { to retain / } \\
\text { remove } \\
\text { items }\end{array}$ \\
\hline 1 & Team work & 4 & 2 & 100 & 1 & 1 & 0.94 & Retain \\
\hline 2 & Diligence & 4 & 1 & 100 & 1 & 1 & 1.00 & Retain \\
\hline 3 & Academic Integrity & 4 & 1 & 100 & 1 & 1 & 1.00 & Retain \\
\hline 4 & Openness & 3 & 2 & 100 & 1 & 1 & 0.84 & Retain \\
\hline 5 & Initiative & 4 & 2 & 100 & 1 & 1 & 0.91 & Retain \\
\hline 6 & Experimentation & 3.5 & 2 & 100 & 1 & 1 & 0.88 & Retain \\
\hline 7 & Assertiveness & 2 & 2 & 62.5 & 0.25 & 0.25 & 0.56 & Remove \\
\hline 8 & Fairness & 3 & 2 & 62.5 & 1 & 0.25 & 0.84 & Retain \\
\hline 9 & Adaptability & 3.5 & 2 & 100 & 1 & 1 & 0.88 & Retain \\
\hline 10 & Creativity & 3.5 & 2 & 100 & 1 & 1 & 0.88 & Retain \\
\hline 11 & Personality development & 3.5 & 3 & 75 & 0.75 & 0.5 & 0.81 & Retain \\
\hline 12 & Courtesy & 3 & 3 & 62.5 & 0.63 & 0.25 & 0.72 & Remove \\
\hline 13 & Cautiousness & 3 & 3 & 75 & 0.75 & 0.5 & 0.75 & Retain \\
\hline 14 & Equality in opportunities & 3 & 3 & 87.5 & 0.63 & 0.75 & 0.63 & Retain \\
\hline 15 & Economy & 2 & 5 & 50 & 0.25 & 0 & 0.50 & Remove \\
\hline 16 & Recognition & 3 & 2 & 87.5 & 0.75 & 0.75 & 0.69 & Retain \\
\hline 17 & Formality & 2 & 5 & 50 & 0.25 & 0 & 0.50 & Remove \\
\hline 18 & Humor & 3 & 3 & 87.5 & 0.88 & 0.75 & 0.75 & Retain \\
\hline 19 & Forgiveness & 3 & 2 & 87.5 & 0.75 & 0.75 & 0.69 & Retain \\
\hline 20 & Broad-mindedness & 2.5 & 4 & 62.5 & 0.5 & 0.5 & 0.50 & Remove \\
\hline 21 & Logic & 3.5 & 2 & 100 & 1 & 1 & 0.88 & Retain \\
\hline 22 & Academic Freedom & 4 & 2 & 100 & 1 & 1 & 0.94 & Retain \\
\hline 23 & Obedience & 3 & 3 & 100 & 0.75 & 1 & 0.78 & Retain \\
\hline 24 & Orderliness & 3 & 3 & 100 & 0.75 & 1 & 0.72 & Retain \\
\hline & & & & & &
\end{tabular}




\begin{tabular}{c|l|c|c|c|c|c|c|c}
\hline 25 & Meritocracy & 3 & 2 & 100 & 1 & 1 & 0.81 & Retain \\
\hline 26 & Intellectual Excellence & 3.5 & 3 & 100 & 0.75 & 1 & 0.81 & Retain \\
\hline 27 & Innovation & 3 & 2 & 75 & 1 & 0.5 & 0.81 & Retain \\
\hline 28 & Advance knowledge & 3 & 2 & 100 & 1 & 1 & 0.78 & Retain \\
\hline 29 & Spirit of participation & 4 & 2 & 100 & 1 & 1 & 0.91 & Retain \\
\hline 30 & Quality Education & 3.5 & 2 & 100 & 1 & 1 & 0.88 & Retain \\
\hline 31 & Benefit of society & 3 & 2 & 100 & 1 & 1 & 0.84 & Retain \\
\hline 32 & Competent & 3 & 2 & 100 & 1 & 1 & 0.84 & Retain \\
\hline 33 & Tech-savvy & 3 & 2 & 100 & 1 & 1 & 0.78 & Retain \\
\hline & $\begin{array}{l}\text { Emerging as an effective } \\
\text { professional }\end{array}$ & & & & & & \\
34 & leaders/skills/entrepreneurs & 2 & 3 & 49 & 0.75 & 1 & 0.42 & Remove \\
\hline 35 & commitment & 2 & 3 & 49 & 0.75 & 1 & 0.42 & Remove \\
\hline 36 & Research & 3.5 & 2 & 100 & 1 & 1 & 0.88 & Retain \\
\hline 37 & Inculcating moral values & 3 & 3 & 100 & 0.75 & 1 & 0.75 & Retain \\
\hline
\end{tabular}

\section{Exploratory Factor Analysis (EFA)}

The final list of values was taken for further analysis. The questionnaire was distributed to 350 respondents based on the item ratio method. For employing exploratory factor analysis, Nunnally (1978, p.421) suggested that for doing EFA, the subject to item ratio should be at least 10:1 and 5 to 10 observations (Comrey \& Lee, 1992). In this study, 30 items have been included and therefore the sample size should be at least 300 .

In the present study, the questionnaire was distributed to 350 faculty members working in higher educational institutions. Out of 350, the questionnaire was collected from 341 respondents. Hence, the response rate is $97.4 \%$. 10 respondents were removed from the analysis because some data were missing. Finally, 331 respondents were included in the analysis. The value statements were made into 5 point Likert scale. The scale represented the following ratings: not at all important $=1$, unimportant $=2$, neutral $=3$, important $=4$, and very important $=5$.

Factor analysis followed mathematical procedures for summarizing the interrelated variables to draw structure in a set of variables (Child, 2006). It operated for reducing measurable and observable variables to fewer latent variables by sharing a common variance among them (Bartholomew et al., 2011). EFA is applied to reveal any latent variable that causes the manifest variables to covary. The main aim of EFA is to group the correlated variables under some common factors (McDonald, 1985). EFA is used to assess the variables which 'go together' and to determine the underlying factors (DeCoster, 1998). During factor extraction, the shared variance of a variable is partitioned from its unique variance and error variance to reveal the underlying factor structure; only shared variance appears in the solution. The present study has followed maximum likelihood extraction method and promax rotation method for performing EFA.

\section{Analysis and Interpretation}

Before doing the analysis, the dataset need to be determined that is suitable for EFA. The value of Bartlett's Test of Sphericity (significant level $\mathrm{p}<0.05$ ) show the patterned relationship among the variables. The table 7 shows $p<0.001$ and the dataset is suitable for 


\section{Macrothink}

International Journal of Human Resource Studies

ISSN 2162-3058 2018, Vol. 8, No. 2

EFA. Also, we need to look at Kaiser-Meyer-Olkin Measure (KMO) of Sampling Adequacy (cut-off above 0.05) value. The table 7 represents the KMO of sampling adequacy value which is above cut-off $(0.835)$. Thus, the initial process satisfied the requirements for performing EFA.

Table 7. SPSS output for KMO and Bartlett's test

KMO and Bartlett's Test

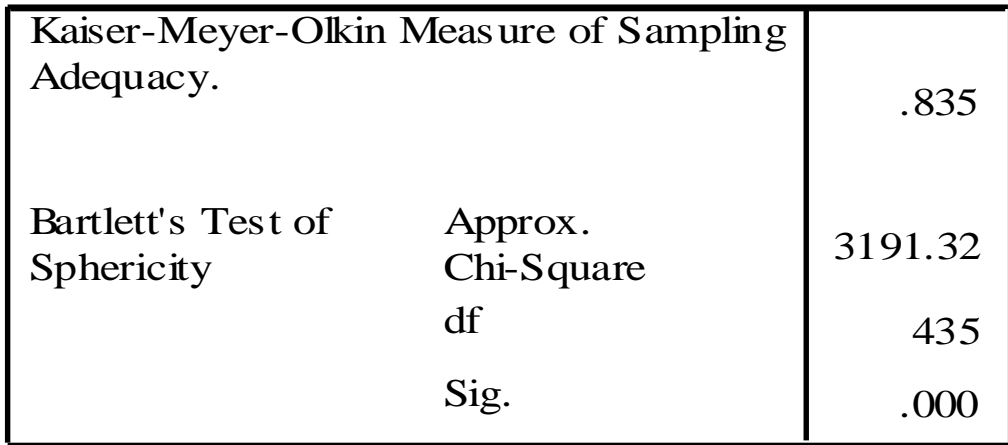

Table 8. SPSS output for the total variance explained for extracted factors

Total Variance Explained

\begin{tabular}{|l|r|r|r|r|r|r|r|}
\hline \multirow{2}{*}{ Factor } & \multicolumn{3}{|c|}{ Initial Egenvalues } & \multicolumn{2}{c|}{ Extraction Sums of Squared Loadings } & Rotation \\
\cline { 2 - 8 } & \multicolumn{1}{|c|}{ Total } & \% of Variance & Cumulative \% & \multicolumn{1}{c|}{ Total } & $\%$ of Variance & Cumulative \% & Total \\
\hline 1 & 7.049 & 23.496 & 23.496 & 6.492 & 21.641 & 21.641 & 4.860 \\
2 & 2.694 & 8.980 & 32.476 & 2.121 & 7.070 & 28.710 & 3.178 \\
3 & 1.678 & 5.593 & 38.069 & 1.120 & 3.732 & 32.442 & 2.849 \\
4 & 1.661 & 5.536 & 43.605 & 1.000 & 3.334 & 35.776 & 3.796 \\
5 & 1.526 & 5.087 & 48.691 & 1.050 & 3.501 & 39.278 & 1.644 \\
6 & 1.180 & 3.935 & 52.626 & .714 & 2.382 & 41.659 & 3.221 \\
7 & 1.125 & 3.750 & 56.376 & .558 & 1.861 & 43.520 & 2.634 \\
8 & .984 & 3.278 & 59.654 & & & & \\
\hline
\end{tabular}

Extraction Method: Maximum Likelihood.

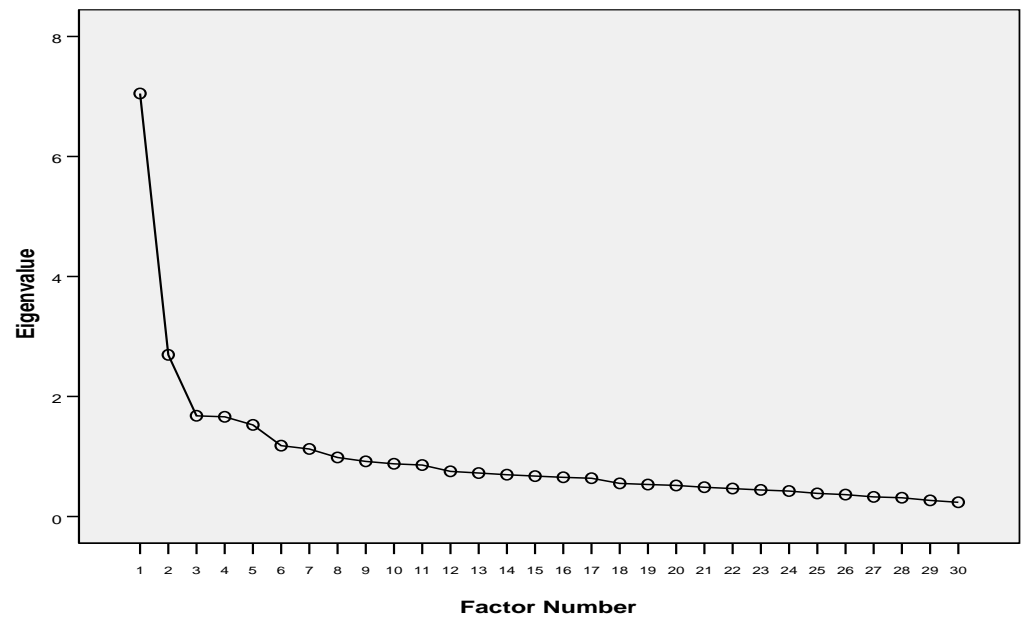

Figure 1. SPSS output for Scree Plot indicating that the data have seven factors 
The table 8 shows the total variance explained to determine the number of significant factors. The initial eigen values and extraction sums of squared loadings are shown in this table. The factors are arranged in the descending order based on the most explained variance. There are 7 factors extracted based on the eigen value (eigen value greater than 1). The factors which were extracted denoted 56. $38 \%$ of variance. The figure 1 clearly shows the Scree plot of significant factors. Both table 8 and figure 1 indicate the extraction of seven factors. The list consists of 30 value items and among them only one item 'teamwork' got very low communality value $(0.226)$ and hence it was removed for the further analysis. The remaining items have the communalities above 0.4. The item communalities are considered 'high', if they are all 0.8 and above (Velicer and Fava, 1998). But, the moderate communalities of 0.4 to 0.7 are acceptable by the researchers.

Table 9. SPSS output for Pattern Matrix after Promax rotation method

Pattern Matrix ${ }^{\mathrm{a}}$

\begin{tabular}{|c|c|c|c|c|c|c|c|}
\hline & \multicolumn{7}{|c|}{ Factor } \\
\hline & 1 & 2 & 3 & 4 & 5 & 6 & 7 \\
\hline p22 & .627 & & & & & & \\
\hline p19 & .582 & & & & & & \\
\hline p30 & .558 & & & & & & \\
\hline p20 & .544 & & & & & & \\
\hline p16 & .541 & & & & & & \\
\hline p23 & .519 & & & & & & \\
\hline p21 & .458 & & & & & & \\
\hline p24 & .451 & & & & & & \\
\hline p10 & .438 & & & & & & \\
\hline p11 & & .625 & & & & & \\
\hline p5 & & .595 & & & & & \\
\hline p7 & & .546 & & & & & \\
\hline p3 & & .535 & & & & & \\
\hline p2 & & .374 & & & & & \\
\hline p15 & & & .716 & & & & \\
\hline p14 & & & .608 & & & & \\
\hline p9 & & & .445 & & & & \\
\hline p26 & & & & .794 & & & \\
\hline p25 & & & & . 466 & & & \\
\hline p17 & & & .328 & . 440 & & & \\
\hline p27 & & & & .362 & & & \\
\hline p18 & & & & & .601 & & \\
\hline $\mathrm{p} 4$ & & & & & .369 & & \\
\hline p8 & & & & & .368 & & \\
\hline $\mathrm{p} 1$ & & & & & & & \\
\hline p29 & & & & & & .541 & \\
\hline p6 & & & & & & .508 & \\
\hline p28 & & & & & & .472 & \\
\hline p12 & & & & & & & .739 \\
\hline p13 & & & & .365 & & & .466 \\
\hline
\end{tabular}

Extraction Method: Maximum Likelihood. Rotation Method: Promax with Kaiser Normalization.

a. Rotation converged in 13 iterations. 


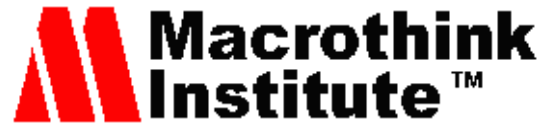

Table 9 shows the variables grouped together under common factors based on the interrelation among them. There is a good rule of thumb that the minimum loading of item should be 0.32 and above (Tabachnick and Fidell, 2001). There are chances for 'cross loading' or 'split loading' which means that an item could be loaded on two or more factors having the loading at 0.32 . If there are several cross loaders, then the items may be poorly written. Also, it is very significant to notify the number of variables placed in a factor. The factor 7 shows only two variables placed on it and the two items p13 and p17 were cross loadings on two factors. A factor with fewer than three items is generally weak and unstable factor. Hence, the items p12 (equality in opportunities), p13 (cautiousness), p17 (academic freedom) (cross-loading), p1 (low communality -0.154) were removed and the analysis has been carried out again.

Table 10 shows the total variance of the factors after the removal of four items, the rotation has extracted six factors and at least three variables presented in each factor and the total variance is $53.76 \%$. The table 11 shows the pattern matrix and the number of factors after removing two items. The factor loadings less than 0.32 are not shown in table 9 and 11 . Figure 2 denotes the six factors based on the Eigen value, and the reference line is drawn at the break point. There are six data points above the break. After the sixth data point, the bend becomes flatten. Hence, six factors are retained for the further explanation. The table 12 represents the correlation among the factors. All the factors are correlated among them.

Table 10. Extraction of six factors after removing four items (p12, p13, p17, and p1)

Total Variance Explained

\begin{tabular}{|c|c|c|c|c|c|c|c|}
\hline \multirow[b]{2}{*}{ Factor } & \multicolumn{3}{|c|}{ Initial Eigen values } & \multicolumn{3}{|c|}{$\begin{array}{c}\text { Extraction Sums of Squared } \\
\text { Loadings }\end{array}$} & $\begin{array}{c}\text { Rotation Sums of } \\
\text { Squared } \\
\text { Loadings(a) }\end{array}$ \\
\hline & Total & $\begin{array}{c}\% \text { of } \\
\text { Variance }\end{array}$ & Cumulative \% & Total & $\begin{array}{c}\% \text { of } \\
\text { Variance }\end{array}$ & Cumulative \% & Total \\
\hline 1 & 6.319 & 24.304 & 24.304 & 5.746 & 22.100 & 22.100 & 4.648 \\
\hline 2 & 2.667 & 10.257 & 34.561 & 2.078 & 7.994 & 30.094 & 3.124 \\
\hline 3 & 1.599 & 6.148 & 40.709 & 1.036 & 3.986 & 34.080 & 2.730 \\
\hline 4 & 1.440 & 5.537 & 46.246 & .834 & 3.207 & 37.287 & 2.925 \\
\hline 5 & 1.306 & 5.023 & 51.269 & .813 & 3.127 & 40.414 & 3.060 \\
\hline 6 & 1.116 & 4.292 & 55.561 & .573 & 2.204 & 42.618 & 1.442 \\
\hline
\end{tabular}

Extraction Method: Maximum Likelihood.

a When factors are correlated, sums of squared loadings cannot be added to obtain a total variance. 
Scree Plot

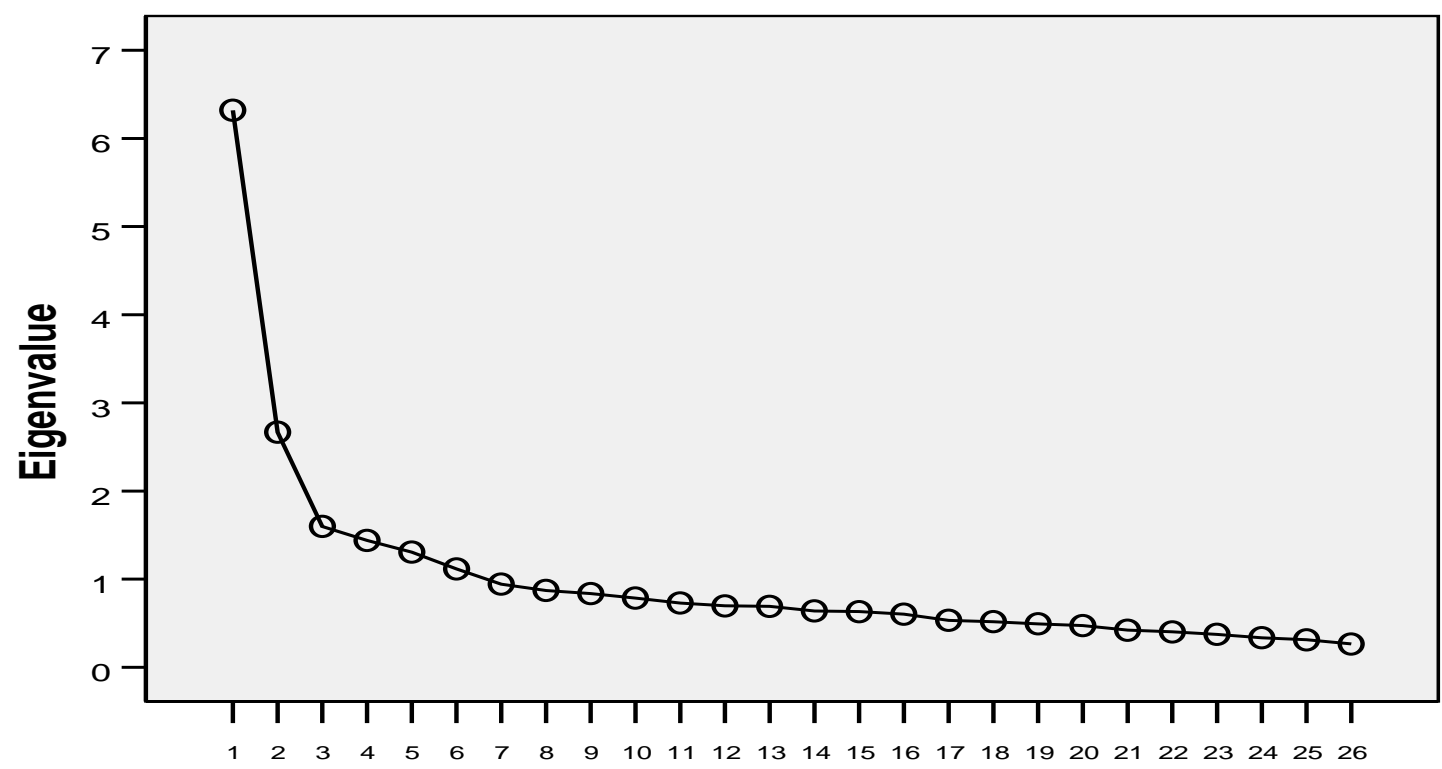

Factor Number

Figure 2. SPSS output of Scree Plot after the removal of four items

Table 11. SPSS output for Pattern Matrix after the removal of four items

Pattern Matrix

\begin{tabular}{|c|c|c|c|c|c|c|}
\hline & \multicolumn{6}{|c|}{ Factor } \\
\hline & 1 & 2 & 3 & 4 & 5 & 6 \\
\hline p19 & .643 & & & & & \\
\hline p20 & .604 & & & & & \\
\hline p22 & .581 & & & & & \\
\hline p16 & .576 & & & & & \\
\hline p30 & .556 & & & & & \\
\hline p23 & .549 & & & & & \\
\hline p21 & .490 & & & & & \\
\hline p10 & .490 & & & & & \\
\hline p24 & . 442 & & & & & \\
\hline p11 & & .658 & & & & \\
\hline p5 & & 612 & & & & \\
\hline p3 & & .550 & & & & \\
\hline p7 & & .512 & & & & \\
\hline p2 & & . 387 & & & & \\
\hline p15 & & & .742 & & & \\
\hline p14 & & & .627 & & & \\
\hline p9 & & & .431 & & & \\
\hline p26 & & & & .809 & & \\
\hline p25 & & & & .436 & & \\
\hline p27 & & & & .349 & & \\
\hline p6 & & & & & .595 & \\
\hline p29 & & & & & .542 & \\
\hline p28 & & & & & & \\
\hline p18 & & & & & & .623 \\
\hline $\mathrm{p} 4$ & & & & & & .401 \\
\hline p8 & & & & & & .328 \\
\hline
\end{tabular}




\section{Ml Macrothink}

Extraction Method: Maximum Likelihood.

Rotation Method: Promax with Kaiser Normalization.

a Rotation converged in 11 iterations.

\section{Labeling the Factors}

The exploratory factor analysis has extracted 6 factors. Based on the grouped variables, the factors are labeled. The first factor, labeled 'cognitive values' contains nine items: personality development, logic, orderliness, meritocracy, innovation, advance knowledge, spirit of participation, inculcating moral values, and intellectual excellence. The second factor, labeled 'meticulous values' contains five items: diligence, academic integrity, initiative, cautiousness, and fairness. The third factor, labeled 'sensible values' contains three items: creativity, humor, and forgiveness. The fourth factor, labeled 'proficiency values' contains three items: quality education, benefit of society, and competent. The fifth factor, labeled 'exploration values' contains three items: experimentation, tech-savvy, and research. The sixth factor, labeled 'behavioral values' contains three items: openness, adaptability, and obedience.

\section{Confirmatory Factor Analysis (CFA)}

CFA is a measurement model and it is used when the researcher postulates relations between the observed measures and the underlying factors 'a priori', based on knowledge of the theory, empirical research, or both, and then tests this hypothesized structure statistically. The primary task of CFA is to determine the goodness-of-fit between the hypothesized model and the sample data. It characterizes how the measured variables come together to represent constructs and are used for validation and reliability checks.

The ideal level of standardized loadings for reflective indicators is 0.70 , but 0.60 is considered to be an acceptable level (Barclay et al., 1995). In this current study, the questionnaire has been distributed to the teaching members of various Engineering colleges in India. The respondents have been asked to rate the values in two methods. In one hand, the respondents have been instructed to rate how much importance they give (personal values) to a specific item and on the other hand, they have to rate how much importance that their institution offers (perceived organizational values).The CFA has been employed for both these responses and shown an acceptable overall model fit. 


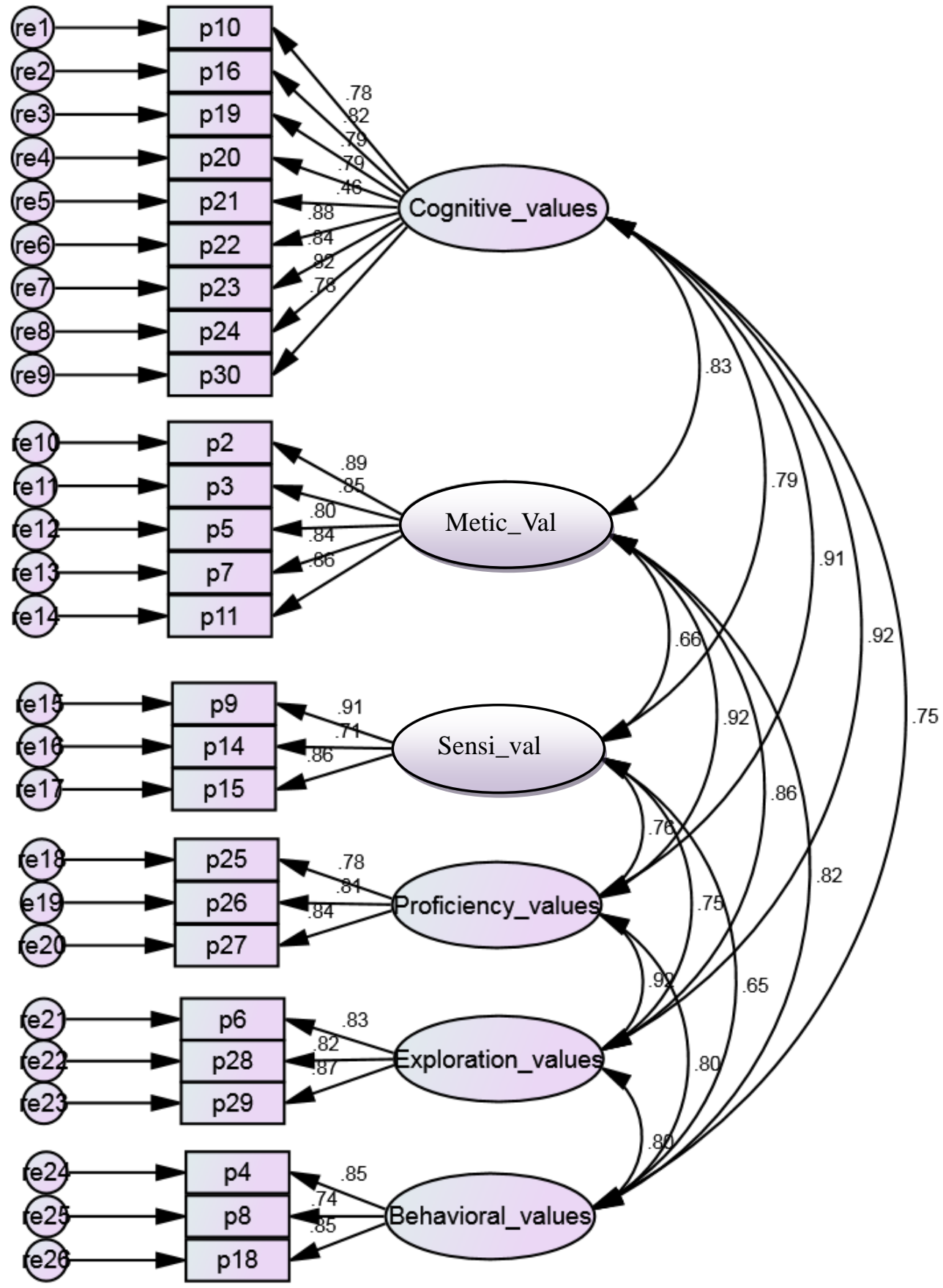

Figure 3. Confirmatory analysis for Personal values 


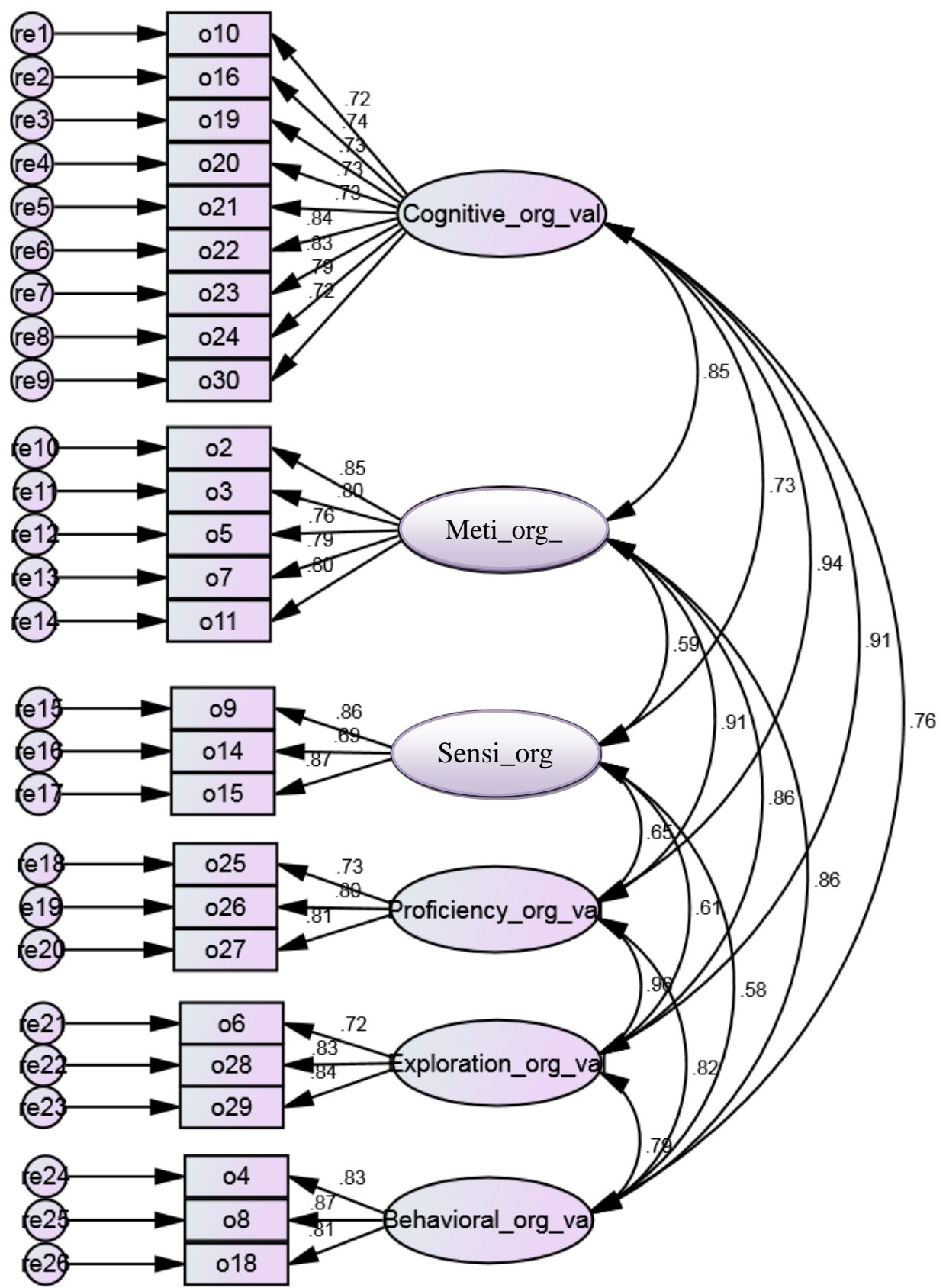

Figure 4. Confirmatory analysis for Perceived organizational values

A confirmatory factor analysis was employed using AMOS structural equation software. To do CFA, data was collected from 350 respondents. The following indices were used for evaluating the fit of the model to the data. A test of overall fit of the baseline model was carried out across organizations, resulting in the following indices: for personal values, chi-square $=843.818$, $\mathrm{df}=284, \quad \mathrm{chi}-\mathrm{sq} / \mathrm{df}=2.971, \quad \mathrm{CFI}=0.931, \quad \mathrm{RMSEA}=0.074 ; \quad$ for organizational values, chi-sq=800.309, $\mathrm{df}=284, \mathrm{chi}-\mathrm{sq} / \mathrm{df}=2.818, \mathrm{CFI}=0.925, \mathrm{RMSEA}=0.072$. Thus, the baseline model was considered as an acceptable fit to the data.

The following indices were used for evaluating the fit of the model to the data: chi-sq/df 
(acceptable value, <3); comparative fit index (CFI), (acceptable value at least 0.90); and root mean squared error of approximation (RMSEA) (acceptable values <0.08), (Kline, 1998; Byrne 2001). The standardized loadings for all the indicators are greater than 0.7. But, it is greater than 0.6 for the indicator 'humor' in organizational values. Barclay et al. (1995) suggested that the standardized loadings greater that 0.6 is acceptable. Therefore, all the loadings are within the acceptable range. The standardized regression weights (factor loadings), Cronbach alphas, model of fit indices for personal and perceived organizational values of all respondents are reported in Table 12.

Table 12. Standardized regression weights (factor loadings), Cronbach alpha value, Model of fit indices for personal and organizational values

\begin{tabular}{|c|c|c|c|}
\hline Factor & Value & $\begin{array}{l}\text { Personal } \\
\text { values }\end{array}$ & $\begin{array}{c}\text { Perceived } \\
\text { organizational } \\
\text { values }\end{array}$ \\
\hline $\begin{array}{l}\text { Cognitive } \\
\text { values }\end{array}$ & $\begin{array}{l}\text { Personality development } \\
\text { Logic } \\
\text { Orderliness } \\
\text { Meritocracy } \\
\text { Intellectual Excellence } \\
\text { Innovation } \\
\text { Advance knowledge } \\
\text { Spirit of participation } \\
\text { Inculcating moral values } \\
\text { Alpha value }\end{array}$ & $\begin{array}{c}0.776 \\
0.818 \\
0.79 \\
0.788 \\
0.763 \\
0.877 \\
0.841 \\
0.815 \\
0.784 \\
(\mathbf{0 . 9 4 2 )}\end{array}$ & $\begin{array}{l}0.717 \\
0.736 \\
0.726 \\
0.734 \\
0.732 \\
0.845 \\
0.827 \\
0.793 \\
0.724 \\
(\mathbf{0 . 9 2 3 )}\end{array}$ \\
\hline $\begin{array}{l}\text { Meticulous } \\
\text { values }\end{array}$ & $\begin{array}{l}\text { Diligence } \\
\text { Academic Integrity } \\
\text { Initiative } \\
\text { Recognition } \\
\text { Fairness } \\
\text { Alpha value }\end{array}$ & $\begin{array}{l}0.885 \\
0.854 \\
0.802 \\
0.841 \\
0.855 \\
\mathbf{( 0 . 9 2 7 )}\end{array}$ & $\begin{array}{c}0.853 \\
0.797 \\
0.757 \\
0.79 \\
0.797 \\
(\mathbf{0 . 8 9 8})\end{array}$ \\
\hline Sensible values & $\begin{array}{l}\text { Creativity } \\
\text { Humor } \\
\text { Forgiveness } \\
\text { Alpha value }\end{array}$ & $\begin{array}{l}0.911 \\
0.706 \\
0.863 \\
(\mathbf{0 . 8 6})\end{array}$ & $\begin{array}{c}0.858 \\
0.694 \\
0.87 \\
(\mathbf{0 . 8 4 4 )}\end{array}$ \\
\hline $\begin{array}{l}\text { Proficiency } \\
\text { values }\end{array}$ & $\begin{array}{l}\text { Quality education } \\
\text { Benefit of society } \\
\text { Competent } \\
\text { Alpha value }\end{array}$ & $\begin{array}{c}0.776 \\
0.809 \\
0.839 \\
(\mathbf{0 . 8 4 9})\end{array}$ & $\begin{array}{l}0.731 \\
0.803 \\
0.814 \\
\mathbf{( 0 . 8 2 5 )}\end{array}$ \\
\hline $\begin{array}{l}\text { Exploration } \\
\text { values }\end{array}$ & $\begin{array}{l}\text { Experimentation } \\
\text { Tech-savvy } \\
\text { Research } \\
\text { Alpha value }\end{array}$ & $\begin{array}{c}0.826 \\
0.824 \\
0.87 \\
(\mathbf{0 . 8 7 7})\end{array}$ & $\begin{array}{l}0.724 \\
0.827 \\
0.838 \\
(\mathbf{0 . 8 3 7})\end{array}$ \\
\hline $\begin{array}{l}\text { Behavioral } \\
\text { values }\end{array}$ & $\begin{array}{l}\text { Openness } \\
\text { Adaptability } \\
\text { Obedience } \\
\text { Alpha value }\end{array}$ & $\begin{array}{c}0.854 \\
0.739 \\
0.853 \\
\mathbf{( 0 . 8 5 3 )}\end{array}$ & $\begin{array}{l}0.834 \\
0.868 \\
0.809 \\
(\mathbf{0 . 8 7 5})\end{array}$ \\
\hline $\begin{array}{c}\text { Model of fit } \\
\text { indices } \\
\text { Chi-sq } \\
\text { df } \\
\text { Chi-sq/df } \\
\text { CFI } \\
\text { RMSEA }\end{array}$ & $\begin{array}{c}\text { Acceptable Range } \\
- \\
-\overline{0} \\
>0.3 \\
<0.90 \\
<0.08\end{array}$ & $\begin{array}{c}842.856 \\
284 \\
2.968 \\
0.933 \\
0.074\end{array}$ & $\begin{array}{c}800.309 \\
284 \\
2.818 \\
0.925 \\
0.072\end{array}$ \\
\hline
\end{tabular}

CFI - comparative fit index; RMSEA - root mean squared error of approximation 


\section{Reliability Test}

Reliability test has been used to identify the validation of questionnaire. After the factor analysis, it is significant to determine whether the factors are reliable and can be measured for further exploration.

To assess the reliability of the scale, the Cronbach's alpha method has been applied. Gliem and Gliem (2003) presented the guidelines to evaluate reliability coefficient; alpha value greater than 0.7 is acceptable; greater than 0.6 is questionable; greater than 0.8 is good. Nunnally and Bernstein (1994) suggested a rule of thumb level of higher than 0.70 , with a level as low as 0.60 being accepted for new scale.

The Cronbach's alpha value for personal values: cognitive values (0.942), meticulous values (0.927), sensible values (0.86), proficiency values (0.849), exploration values $(0.877)$, and behavioral values $(0.853)$; for organizational values: cognitive values $(0.923)$, meticulous values $(0.898)$, sensible values $(0.844)$, proficiency values $(0.825)$, exploration values $(0.837)$, and behavioral values (0.875) are accepted as suggested by Gliem and Gliem (2003) and Nunnally and Bernstein (1994). Therefore, it has been confirmed that the scale is reliable for measuring shared values.

\section{Conclusion}

The present study has presented the list of shared values from academic perspective. The list of values has been formulated from McDonald and Gandz (1991) taxonomy of values. Some of the values like diligence, openness, initiative, experimentation, orderliness, obedience, etc., from business perspective are suitable for academic institutions too. The other values which are especially for academic institutions have been derived by means of interview and documents. The qualitative statements have been given by various generation groups (Baby boomers, Gen X and Gen Y) such as teaching staff, non-teaching staff, scholars and students, and collected from printed documents as well. The collected statements have been changed as single statement and submitted to the experts to determine the content validity.

There have been 8 experts involved in doing the process of content validity and they gave the validity ratings as well as suggestions. Out of 37 items, 7 items have been deleted based on the judge's ratings. The remaining 30 items have been taken for factor analysis. The maximum likelihood extraction method has been applied and promax rotation method has been chosen for performing EFA.

The requirements for assessing EFA have been satisfied and there have been seven factors extracted. As the seventh factor consisted of only two variables, it would become unstable. The items p13 and p17 had cross loaded, and p1 has low communality. Hence, four items were removed and the analysis was carried out again. It extracted six factors and at least three variables should be placed on each factor. The factors were named according to the variables grouped. After EFA, CFA was carried out using AMOS software to confirm the factors. The data was collected from 350 respondents to do CFA. Eventually, the reliability test was conducted to determine whether the scale is reliable for further measurement. It was found that Cronbach's alpha value for all the factors for both personal and organizational values had 
been greater than 0.7 which is acceptable. Hence, this scale can be taken for promoting future studies for finding the relationship between the values and work attitude variables, behaviours, and various individual and organizational outcomes of various generational cohorts in academic institutions because it may provide deeper insight to understand them. This measurement would help the management to understand the value system of various generational groups and provide better organizational culture to attain the goals and success of the institutions.

\section{Reference}

Abbott, G. N., White, F. A., \& Charles, M. A. (2005). Linking values and organizational commitment: A correlational and experimental investigation in two organizations. Journal of Occupational and Organizational pyschology, $78, \quad 531 \quad$ - 551. https://doi.org/10.1348/096317905X26174

Adkins, C. L., Werbel, J. D., \& Russell, C. J. (1994). Judgements of fit in the selection process: The role of work values congruence. Personnel psychology, 47, 605-623. https://doi.org/10.1111/j.1744-6570.1994.tb01740.x

Aiken, L. R. (1985). Three coefficients for analyzing the reliability and validity of ratings. Educational and Psychological Measurement, 45, 131 - 142. https://doi.org/10.1177/0013164485451012

Allport, G. W., Vernon, P. E., \& Lindzey, G. E. (1960). Study of values: A scale for measuring the dominant interests in personality. Houghton Mifflin.

Barclay, D., Higgins, C., \& Thompson, R. (1995). The Partial Least Squares (pls) Approach to Casual Modeling: Personal Computer Adoption Ans Use as an Illustration.

Bartholomew, D. J., Knott, M., \& Moustaki, I. (2011). Latent variable models and factor analysis: A unified approach (Vol. 904). John Wiley \& Sons. https://doi.org/10.1002/9781119970583

Beck, C. T., \& Gable, R. K. (2001). Ensuring content validity: An illustration of the process. Journal of Nursing measurement, 9(2), 201-215.

Bollen, K. A. (1989). Structural equations with latent variables, New York, NY: John Wiley. https://doi.org/10.1002/9781118619179

Brown, D. (2002). The role of work and cultural values in occupational choice, satisfaction, and success: A theoretical statement. Journal of Counseling and Development, 80(1), 48-56. https://doi.org/10.1002/j.1556-6678.2002.tb00165.x

Byrne, B. M. (2001). Structural equation modeling perspectives on the present and the future. International Journal of Testing, $1(3-4), \quad 327 \quad-\quad 334$. https://doi.org/10.1080/15305058.2001.9669479

Cennamo, L., \& Gardner, D. (2008). Generational differences in work values, outcomes and person-organisation values fit. Journal of Managerial Psychology, 23(8), 891-906. 
https://doi.org/10.1108/02683940810904385

Chatman, J. A. (1989). Matching people and organizations: Selection and socialization in public accounting firms. In Academy of Management proceedings, 1989(1), 199-203. Academy of Management. https://doi.org/10.5465/AMBPP.1989.4980837

Child, D. (2006). The essentials of factor analysis, 3rd ed. New York, NY: Continuum International Publishing Group.

Collins, D. (1998). Organizational Change: Sociological Perspectives. London: Routledge.

Comrey, A., \& Lee, H. (1992). A first course in factor analysis. Hillsdale, New Jersey: Lawrence Erlbaum Associates.

Creswell, J. (2003). Research design: Qualitative, quantitative and mixed methods approaches, 2nd ed., Thousand Oaks, SAGE Publications.

DeCoster, J. (1998). Overview of factor analysis. Retrieved February 15, 2017 from http://www.stat-help.com/notes.html.

England, G. W. (1967). Personal value systems of American managers. Academy of Management Journal, 10(1), 53-68. https://doi.org/10.2307/255244

Finegan, J. E. (2000). The impact of person and organizational values on organizational commitment. Journal of Occupational and Organizational Psychology, 73(2), 149-169. https://doi.org/10.1348/096317900166958

Gibson, J. W., Greenwood, R. A., \& Murphy J, E. F. (2009). Generational differences in the workplace: Personal values, beliefs and popular beliefs. Journal of Diversity Management, $4(3), 1-8$.

Gliem J. A., \& Gliem, R. R. (2003) Calculating, Interpreting, and Reporting Cronbach's Alpha Reliability Coefficient for Likert-Type Scales. 2003 Midwest Research to Practice Conference in Adult, Continuing, and Community Education, Columbus, 82-88. Retrieved December 4, 2017 from https://scholarworks.iupui.edu/handle/1805/344.

Hellsten, L. M. (2008). Accumulating content validity evidence: Assessing expert panel ratings of item relevance and representativeness. Paper presented at the 2008 National Council. Measurement in Education Annual Conference. $25^{\text {th }}$ March 2008. New York.

Kline. (1998). Software review: Software programs for structural equation modeling Amos, EQS, and LISREL. Journal of psychoeducational assessment, 16(4), 343-364. https://doi.org/10.1177/073428299801600407

Kristof, A. L. (1996). Person-organization fit: An integrative review of its conceptualizations, measurement, and implications. Personnel Psychology, 49(1), 1-49. https://doi.org/10.1111/j.1744-6570.1996.tb01790.x

Lawrence, A. (2006). Person - organization congruence of high performance values in Australian Universities. International Journal of Knowledge, Culture and Change 
Management, 6(4), 173-182.

Lawrence, A., \& Lawrence, P. (2009). Values congruence and organizational commitment: P-O Fit in Higher educational institutions. Journal of Academic Ethics, 7, 297-314. https://doi.org/10.1007/s10805-010-9103-2

Lawshe, C. H. (1975). A quantitative approach to content validity. Personnel Psychology, 28, 563 - 575. https://doi.org/10.1111/j.1744-6570.1975.tb01393.x

Lynn, M. R. (1986). Determination and quantification of content validity. Nursing Research, 35(6), 382-385. https://doi.org/10.1097/00006199-198611000-00017

Lyons, S. (2004). An exploration of generational values in life and at work. ProQuest Dissertations and Thesis, The Humanities and Social Sciences Collection.

McDonald, P., \& Gandz, J. (1991). Identification of Values relevant to Business Research. Human Resource Management, Summer, 30(2), 217-236. https://doi.org/10.1002/hrm.3930300205

McDonald, P., \& Gandz, J. (1992). Getting value from shared values. Organizational Dynamics, 20, 64-77. https://doi.org/10.1016/0090-2616(92)90025-I

McDonald, R. P. (1985). Factor analysis and related methods. Hillside. NJ: Lawrence Erlbaum Associates, Inc.

Nunnally, J. C. (1978). Psychometric theory, 2nd ed. New York. NY: McGraw-Hill.

Nunnally, J. C., \& Bernstein, I. H. (1994) Psychometric theory, 3rd ed. New York. NY: McGraw-Hill.

Ostroff, C., Shin, Y., \& Kinicki, A. J. (2005). Multiple perspectives of congruence: Relationships between value congruence and employee attitudes. Journal of Organizational Behaviour, 26, 591-623. https://doi.org/10.1002/job.333

Polit, D. F., Beck, C. T., \& Owen, S. V. (2007). Is the CVI an acceptable indicator of content validity? Appraisal and recommendation. Research in Nursing \& Health, 30, 459 - 467. https://doi.org/10.1002/nur.20199

Posner, B. Z. (2010a). Values and the American Manager: A Three Decade Perspective. Journal of Business Ethics, 91(4), 457-465. https://doi.org/10.1007/s10551-009-0098-9

Posner, B. Z. (2010b). Another Look at the Impact of Personal and Organizational Values Congruency. Journal of Business Ethics, 97(4), 535-541. https://doi.org/10.1007/s10551-010-0530-1

Raineri, N., Paille, P., \& Morin, D. (2012). Organizational Citizenship Behaviour: An Intergenerational Study. Revue Internationale De Psychologie Sociale, 25(3), 147-177.

Rogers, W. T. (2010) Educational Psychology 507: The Nature of Validity, Unpublished Manuscript, University of Alberta. 
Rokeach, M. (1973). The nature of human values. New York. NY: The Free Press.

Schwartz, S. H. (1992). Universals in the content and structure of values: Theoretical advances and empirical tests in 20 countries. Advances in Experimental Psychology, 25, 1-65. https://doi.org/10.1016/S0065-2601(08)60281-6

Schwartz, S. H., \& Bardi, A. (2001). Value hierarchies across cultures: Taking a similarities perspective. Journal of Cross Cultural psychology, 32, 268-290. https://doi.org/10.1177/0022022101032003002

Strauss, W., \& Howe, N. (1997) The Fourth Turning: What The Cycles of History Tell Us about Americas Next Rendezvous With Destiny. New York. NY: Broadway Books.

Tabachnick, B. G., \& Fidell, L. S. (2001). Using multivariate statistics. Allyn \& Bacon/Pearson Education.

The Editors of Encyclopaedia Britannica. (2018). Academic Freedom. Retrieved from https://www.britannica.com/topic/academic-freedom.

Velicer, W. F., \& Fava, J. L. (1998). Effects of variable and subject sampling on factor pattern recovery. Psychological Methods, 3, 231-251. https://doi.org/10.1037/1082-989X.3.2.231

Westerman, J. W., \& Vanka, S. (2005). A cross cultural empirical analysis of person-organization fit measures as predictors of student performance in business education: comparing students in the United States and India. Academy of Management Learning and Education, 4, 409 - 420. https://doi.org/10.5465/AMLE.2005.19086783

Yogamalar, I., \& Samuel, A. A. (2016). Shared values and organizational citizenship behavior of generational cohorts: A review and future directions. Management, 21(2), 249 - 271.

Yun, J. K., \& Ulrich, D. (2002). Estimating measurement validity: A tutorial. Adapted Physical Activity Quarterly, 19, 32-34. https://doi.org/10.1123/apaq.19.1.32

\section{Copyright Disclaimer}

Copyright for this article is retained by the author(s), with first publication rights granted to the journal.

This is an open-access article distributed under the terms and conditions of the Creative Commons Attribution license (http://creativecommons.org/licenses/by/4.0/). 